\title{
SOME TECHNOLOGICAL ASPECTS IN IMPROVEMENT OF WEANED PIGS
}

\author{
B. Živković ${ }^{1}$, W. Migdal ${ }^{2}, \check{C C}^{\text {Radović }}{ }^{1}$ \\ ${ }^{1}$ Institute for Animal Husbandry, Zemun-Belgrade, Republic of Serbia \\ ${ }^{2}$ Agricultural University, Faculty of Food Technology, Krakow, Poland \\ Corresponding author: zivkovicbbranislav@yahoo.com \\ Invited paper
}

Abstract: Effects of utilization of imported boars in comparison to domestic ones were investigated, two imported boar lines Tibora and Tempa were compared in regard to production of their progeny, piglets in rearing, and in the final, third trial, possibilities for use of Biokvas preparation as substitute of yeast in nutrition of piglets in rearing were studied. Obtained results showed that considerably better production is realized by improvement of gain by $17,79 \%$ and feed conversion by $12,21 \%$ as well as lower cost of gain by $12,16 \%$ in progeny of imported boars. No differences were established in weaned piglets deriving from two imported boar lines Tibora or Tempa. Considering that better gain in average by $3,88 \%$ and cheaper by $0,57 \%$ was realized, it can be concluded that Biokvas as a protein feed can succesfully be used as substitute for yeast in nutiriton of piglets in rearing. In general, use of imported boars as well as application of Biokvas instead of yeast in nutrition of piglets and with objective of improvement of production of rearing piglets were justified.

Key words: boars, Biokvas, yeast, weaned pigs

\section{Introduction}

Successful weaning of piglets and prevention of disturbances in this phase are possible only with high quality nutrition and adequate structure of diet (Kovčin, 1993).

Age of four weeks is accepted as optimal time for weaning of piglets since it is considered that this age is optimal from the aspect of number of farrowings and production of piglets per sow annually. From the aspect of development of digestive tract, age of four weeks is the most critical period in the life cycle of pigs. Many pig producers experience numerous problems in nutrition and rearing of piglets after weaning, especially in the first 7-10 days when mortality is often very high, caused by disturbances of digestive tract and incidence of diarrhea in young piglets. Consequently, objective of every progressive pig breeder is to realize high 
body mass in piglets at weaning and to get them used to food prior to weaning so that there are no problems in digestion of food (Živković and Kovčin, 1986).

Objective of this paper was to investigate some of the factors such as origin of boars (imported compared to domestic) on body mass of piglets at weaning and later production in rearing, as well as possibility for introduction of protein feed Biokvas instead of yeast in piglet rearing.

\section{Materials and Methods}

Investigations were carried out on private pig farm Fencaroš in Platičevo Šabac. In three trials total of 56 weaned piglets, crosses of Large yorkshire and Swedish Landrace were included. Trials were established immediately after weaning and it lasted 39 feeding days, with piglets of same age at weaning.

In the first trial the effect of imported boars was investigated (Top Pigs from The Netherlands) compared to domestic boars used on the farm. In the second trial two boar lines Tibor and Tempo were studied and their influence on production of rearing piglets, and in the third trial, nutritive value of protein feed Biokvas manufactured in the production facility of company Bankom in Serbia was analyzed in comparison to yeast in mixtures for weaned piglets.

At weaning, based on standard criteria such as sex, origin and intial body mass, piglets were divided into groups as uniform as possible in regard to age and body mass and without siblings in one group, for all three trials. Every group contained 14 animals, with equal sex ratio.

Animals were fed flour mixtures and received water ad libitum. Subsequent to weaning, piglets were fed pre-starter with approx. $22 \%$ of crude protein, for the period of 10 days, to body mass of $15 \mathrm{~kg}$ they were fed starter with approx. $20 \%$ of crude protein, and to the end of trial grower mixtures with $18 \%$ of crude proteins.

In assessment of obtained results following indicators were taken into consideration: average daily gain of piglets, average daily food consumption, intake of food for $1 \mathrm{~kg}$ of gain, as well as economical justification for nutrition expressed by cost of $\mathrm{kg}$ of gain.

Obtained results were processed statistically using variance analysis, and differences between average values were tested using t-test. 


\section{Results and Discussion}

\section{$\underline{\text { Trial I }}$}

In the first trial production, economical results in two groups of rearing piglets were monitored. In the first group, paternal component were imported boars, and in the second group piglets were offspring of domestic boars.

Obtained results showed that in the first trial period from $11-20 \mathrm{~kg}$ of body mass of piglets, first group consisting of progeny of imported boars realized average daily gain of $333 \mathrm{~g}$, with consumption of food of $0,568 \mathrm{~kg}$ and feed conversion of $1,71 \mathrm{~kg}$.

In the second group, piglets deriving from domestic boars showed slower growth rate in average by $63 \mathrm{~g}$ or $18,92 \%$, lower feed conversion in average by $0,050 \mathrm{~kg}$ or $8,80 \%$, and lower feed conversion in average by $0,22 \mathrm{~kg}$ or $12,86 \%$ compared to piglets of the first group which are offspring of imported boars.

In the second trial period, from $20-27 \mathrm{~kg}$, first group of piglets realized higher gain, in average by $97 \mathrm{~g}$ or $15,55 \%$, better feed consumption in average by $0,053 \mathrm{~kg}$ or $4,91 \%$, with more favourable in average by $0,22 \mathrm{~kg}$ or $12,72 \%$, consumption of food per $1 \mathrm{~kg}$ of gain, compared to second group consisting of offspring of domestic boars.

For entire trial period, the second group of piglets deriving from domestic boars realized higher daily gain $342 \mathrm{~g}$, with average food consumption of $0,661 \mathrm{~kg}$ and consumption of food per $1 \mathrm{~kg}$ of gain of $1,93 \mathrm{~kg}$. Use of imported boars (lines Tibor and Tempo) improved gain in rearing piglets in average by $74 \mathrm{~g}$ or $17,79 \%$, with higher food consumption in average by $7,16 \%$, and better feed conversion in average by $0,21 \mathrm{~kg}$ or $12,21 \%$, compared to piglets of same age deriving from domestic boars.

Based on consumption of food, cost of $1 \mathrm{~kg}$ of mixture used for feeding of piglets in trial was similar (difference was only $0,34 \%$ ). Considering considerably more favourable feed conversion of $1,72 \mathrm{~kg}$ in comparison to $1,93 \mathrm{~kg}$, it was concluded that cost of $1 \mathrm{~kg}$ of gain in rearing piglets deriving from imported boars was by $12,16 \%$ lower than value obtained for progeny of domestic boars.

\section{$\underline{\text { Trial II }}$}

In the second trial, objective of research was to compare production and economical results in rearing piglets progeny of two imported boar lines. Piglets from the first group are offspring of boar line Tibor, and piglets in the second group are offspring of boar Tempo. 
Table 1. Performance and economic parameters of weaned pigs, trial I

\begin{tabular}{|c|c|c|}
\hline Group & 1 & 2 \\
\hline Imported boars & + & - \\
\hline Domestic boars & - & + \\
\hline \multicolumn{3}{|c|}{ Weaned pigs, $11-20 \mathrm{~kg}$} \\
\hline $\begin{array}{l}\text { Average live weight of piglets at the beginning of } \\
\text { experiment, } \mathrm{kg}\end{array}$ & $11.11^{\mathrm{a}^{*}}$ & $10.07^{\mathrm{a}}$ \\
\hline $\begin{array}{l}\text { Average live weight of piglets at the end of } 1^{\text {st }} \text { period of } \\
\text { experiment, } \mathrm{kg}\end{array}$ & $20.43^{\mathrm{B}}$ & $17.60^{\mathrm{B}}$ \\
\hline Average daily gain, $g$ & $333^{\mathrm{c}}$ & $270^{\mathrm{c}}$ \\
\hline In the comparison to $1^{\text {st }}$ group, $\%$ & - & -18.92 \\
\hline Average daily feed consumption, $\mathrm{kg}$ & 0.568 & 0.518 \\
\hline In the comparison to $1^{\text {st }}$ group, $\%$ & - & -8.80 \\
\hline Feed conversion ratio, $\mathrm{kg}$ & 1.71 & 1.93 \\
\hline In the comparison to $1^{\text {st }}$ group, $\%$ & - & -12.86 \\
\hline \multicolumn{3}{|c|}{ Weaned pigs, $20-27 \mathrm{~kg}$} \\
\hline $\begin{array}{l}\text { Average live weight of piglets at the beginning of } 2^{\text {nd }} \text { period } \\
\text { of experiment, } \mathrm{kg}\end{array}$ & $20.43^{\mathrm{B}}$ & $17.60^{\mathrm{B}}$ \\
\hline $\begin{array}{l}\text { Average live weight of piglets at the end of } 2^{\text {nd }} \text { period of } \\
\text { experiment, } \mathrm{kg}\end{array}$ & $27.30^{\mathrm{D}}$ & $23.40^{\mathrm{D}}$ \\
\hline Average daily gain, $\mathrm{g}$ & $624^{\mathrm{e}}$ & $527^{\mathrm{e}}$ \\
\hline In the comparison to $1^{\text {st }}$ group, $\%$ & - & -15.55 \\
\hline Average daily feed consumption, $\mathrm{kg}$ & 1.079 & 1.026 \\
\hline In the comparison to $1^{\text {st }}$ group, $\%$ & - & -4.91 \\
\hline Feed conversion ratio, $\mathrm{kg}$ & 1.73 & 1.95 \\
\hline In the comparison to $1^{\text {st }}$ group, $\%$ & - & -12.72 \\
\hline \multicolumn{3}{|c|}{ Weaned pigs, $11-27 \mathrm{~kg}$} \\
\hline $\begin{array}{l}\text { Average live weight of piglets at the beginning of whole } \\
\text { experiment, } \mathrm{kg}\end{array}$ & $11.11^{\mathrm{a}}$ & $10.07^{\mathrm{a}}$ \\
\hline $\begin{array}{l}\text { Average live weight of piglets at the end of whole } \\
\text { experiment, } \mathrm{kg}\end{array}$ & $27.30^{\mathrm{D}}$ & $23.40^{\mathrm{D}}$ \\
\hline Average daily gain, $\mathrm{g}$ & $416^{\mathrm{F}}$ & $342^{\mathrm{F}}$ \\
\hline In the comparison to $1^{\text {st }}$ group, $\%$ & - & -17.79 \\
\hline Average daily feed consumption, $\mathrm{kg}$ & 0.712 & 0.661 \\
\hline In the comparison to $1^{\text {st }}$ group, $\%$ & - & -7.16 \\
\hline Feed conversion ratio, $\mathrm{kg}$ & 1.72 & 1.93 \\
\hline In the comparison to $1^{\text {st }}$ group, $\%$ & - & -12.21 \\
\hline Age of weaned pigs at the end of exp., days & 75 & 75 \\
\hline \multicolumn{3}{|c|}{ Economic analysis of cost of gain } \\
\hline Cost of feed, $\%$ & 100.00 & 99.66 \\
\hline Feed conversion ratio, $\%$ & 100.00 & 112.21 \\
\hline Cost of gain of weaned pigs, $\%$ & 100.00 & 112.16 \\
\hline In the comparison to first group, $\%$ & - & -12.16 \\
\hline
\end{tabular}


In the first trial period, first group of piglets - offspring of Tibor boar line, realized average daily gain of $338 \mathrm{~g}$, average daily consumption of food of $0,566 \mathrm{~kg}$ and fed conversion of 1,68 kg. Piglets of the second group - offspring of boar line Tempo, which is considered as line with favourable effect on production performance of animals, with almost same consumption of food (difference was only $0,003 \mathrm{~kg}$ or $0,53 \%$ ) realized slightly lower average daily gain in average by 10 $\mathrm{g}$ or $2,96 \%$ and slightly lower conversion of food in average by $0,05 \mathrm{~kg}$ or $2,98 \%$ compared to piglets of the first group.

In the second period of rearing, piglets offspring of Tibor line realized average daily gain of $618 \mathrm{~g}$, consumed $1,115 \mathrm{~kg}$ of food daily and realized food consumption per $1 \mathrm{~kg}$ of gain of $1,80 \mathrm{~kg}$.

However, in this period of rearing, the other group consisting of offspring of Tempo boar line realized average daily gain of $630 \mathrm{~g}$, which is better in average by $12 \mathrm{~g}$ or $1,94 \%$ compared to offspring of line Tibor. Animals of this group, consumed less feed in this period in average by $0,073 \mathrm{~kg}$ or $6,55 \%$, compared to first group of piglets.

Feed conversion in the second group of piglets deriving from Tempo line of $1,65 \mathrm{~kg}$ was better in average by $0,15 \mathrm{~kg}$ or $8,33 \%$ compared to other group of animals offspring of Tibor line.

During entire rearing period there was practically no significant difference in regard to gain between compared groups of piglets, $417 \mathrm{~g}$ in the first group and $414 \mathrm{~g}$ in the second group.

Food consumption in the first group of piglets was $0,721 \mathrm{~kg}$, and offspring of Tempo in the second group consumed by $0,18 \mathrm{~kg}$ or $2,50 \%$ less food per feeding day compared to first group.

Piglets of the first group, offspring of boar line Tibor, realized feed conversion of $1,73 \mathrm{~kg}$, and offspring of boar line Tempo had better feed conversion in rearing in average by $0,03 \mathrm{~kg}$ or $1,74 \%$ compared to first group.

Economical analysis of the cost of mixtures showed that based on consumed food cost of mixture in the second group of piglets (Tempo offspring) was by $0,5 \%$ higher compared to cost of mixture for the group with offspring of Tibor.

Considering slightly better feed conversion in group with offspring of boar line Tempo, $1,70 \mathrm{~kg}$ compared to $1,73 \mathrm{~kg}$, cost of gain in this group was by $1,24 \%$ lower than value established for this indicator in rearing of piglets deriving from Tibor line. 
Table 2. Performance and econimical parameters of weaned pigs, experiement II

\begin{tabular}{|c|c|c|}
\hline Group & 1 & 2 \\
\hline Boar line Tibor & + & - \\
\hline Boar line Tempo & - & + \\
\hline \multicolumn{3}{|c|}{ Weaned pigs, $11-20 \mathrm{~kg}$} \\
\hline $\begin{array}{l}\text { Average live weight of piglets at the beginning of the } \\
\text { experiment, } \mathrm{kg}\end{array}$ & 11.07 & 11.14 \\
\hline $\begin{array}{l}\text { Average live weight of piglets at the end of } 1^{\text {st }} \text { period of } \\
\text { experiment, } \mathrm{kg}\end{array}$ & 20.53 & 20.33 \\
\hline Average daily gain, $g$ & 338 & 328 \\
\hline In the comparison to $1^{\text {st }}$ group, $\%$ & - & -2.96 \\
\hline Average daily feed consumption, $\mathrm{kg}$ & 0.566 & 0.569 \\
\hline In the comparison to $1^{\text {st }}$ group, $\%$ & - & +0.53 \\
\hline Feed conversion ratio, $\mathrm{kg}$ & 1.68 & 1.73 \\
\hline In the comparison to $1^{\text {st }}$ group, $\%$ & - & -2.98 \\
\hline \multicolumn{3}{|c|}{ Weaned pigs, $20-27 \mathrm{~kg}$} \\
\hline $\begin{array}{l}\text { Average live weight of piglets at the beginning of the } \\
\text { experiment, } \mathrm{kg}\end{array}$ & 20.53 & 20.33 \\
\hline $\begin{array}{l}\text { Average live weight of piglets at the end of the } \\
\text { experiment, } \mathrm{kg}\end{array}$ & 27.33 & 27.27 \\
\hline Average daily gain, $g$ & 618 & 630 \\
\hline In the comparison to $1^{\text {st }}$ group, $\%$ & - & +1.94 \\
\hline Average daily feed consumption, $\mathrm{kg}$ & 1.115 & 1.042 \\
\hline In the comparison to $1^{\text {st }}$ group, $\%$ & - & -6.55 \\
\hline Feed conversion ratio, $\mathrm{kg}$ & 1.80 & 1.65 \\
\hline In the comparison to $1^{\text {st }}$ group, $\%$ & - & +8.33 \\
\hline \multicolumn{3}{|c|}{ Weaned pigs, $11-27 \mathrm{~kg}$} \\
\hline $\begin{array}{l}\text { Average live weight of piglets at the beginning of the } \\
\text { experiment, } \mathrm{kg}\end{array}$ & 11.07 & 11.14 \\
\hline $\begin{array}{l}\text { Average live weight of piglets at the end of the } \\
\text { experiment, } \mathrm{kg}\end{array}$ & 27.33 & 27.27 \\
\hline Average daily gain, $\mathrm{g}$ & 417 & 414 \\
\hline In the comparison to $1^{\text {st }}$ group, $\%$ & - & -0.72 \\
\hline Average daily feed consumption, $\mathrm{kg}$ & 0.721 & 0.703 \\
\hline In the comparison to $1^{\text {st }}$ group, $\%$ & - & -2.50 \\
\hline Feed conversion ratio, $\mathrm{kg}$ & 1.73 & 1.70 \\
\hline In the comparison to $1^{\text {st }}$ group, $\%$ & - & +1.74 \\
\hline Age of weaned pigs at the end of exp., days & 75 & 75 \\
\hline \multicolumn{3}{|c|}{ Economic analysis of cost of gain } \\
\hline Cost of feed, $\%$ & 100.00 & 100.50 \\
\hline Feed conversion ratio, $\%$ & 100.00 & 98.26 \\
\hline Cost of gain of weaned pigs, $\%$ & 100.00 & 98.76 \\
\hline In the comparison to the first group, $\%$ & - & +1.24 \\
\hline
\end{tabular}

Obtained results in our research show superiority of imported boars, with no significant difference between them, in relation to domestic boars and their offspring in rearing. In regard to imported boars, Klimiene and Klimas (2008) 
stated that it is appropriate, useful to import hem every 3 to 4 years, whereas Ncube et al. (2003) suggested their application even on small pig farms. In comparison of different breeds of imported boars, Bitante (2003) stated the superiority of Durok, and reported better gain of Durok progeny by approx. 5\% (McGloghlin, 2003), and in humid tropical regions Oke et al. (2006) stated that Hempshire proved to be the best terminal breed. In import of boars, Gaugler et al. (1984) suggested crosses since they give by 0,79 more piglets which are heavier in average by $11,72 \%$. However, in some researches the difficulty of assessment if some differences in production can be attributed to genetic or environmental influences, is pointed out (Magowan et al., 2007) or to weaning (Widovski et al., 2008). Therefore, Petkov (2007) stated that it is better to check the quality of boars by test for macro elements and albumines in blood.

\section{$\underline{\text { Trial III }}$}

In nutrition of piglets fish meal which is imported is not so often used. In some of our previous researches the possibilities for utilization of some plant protein sources, alo imported, were analyzed, such as Vita protein 50, (Živković et al., 2007) or domestic - Ecofish meal (Živković et al., 2007; Živković et al., 2008).

This trial is practilly continuance of these researches, since the objective was to determine the nutritive value of yeast and one relatively new protein feed of plant origin known as Biokvas, in nutrition of piglets in rearing.

In the first period of rearing from $10-17 \mathrm{~kg}$ first group of piglets fed mixture based on yeast realized average daily gain of $275 \mathrm{~g}$, with consumption of food of $0,521 \mathrm{~kg}$ per feeding day and feed conversion of $1,90 \mathrm{~kg}$.

Introduction of Biokvas instead of yeast in the second group of piglets caused slower gain in average by $11 \mathrm{~g}$ or $4,0 \%$ compared to piglets fed yeast in mixture. Food consumption in the second group was lower in average by $0,05 \mathrm{~kg}$ or $2,63 \%$ compared to group of piglets fed diet based on yeast.

In the second rearing period from $17-24 \mathrm{~kg}$ piglets fed diets containing yeast realized average daily gain of $491 \mathrm{~g}$, with consumption of food of $0,971 \mathrm{~kg}$ per feeding day and consumption of food per $\mathrm{kg}$ of gain of $1,98 \mathrm{~kg}$.

However, use of Biokvas as yeast substitute in mixture in this period of rearing caused in piglets improvement of growth ratio in average by $72 \mathrm{~g}$ or $14,66 \%$ compared to group of piglets fed diets based on yeast. Piglets fed diet based on Biokvas consumed more food, in average by $0,11 \mathrm{~kg}$ or $11,33 \%$ and realized better feed conversion in average by $0,06 \mathrm{~kg}$ or $3,03 \%$ compared to piglets fed diets containing yeast. 
Table 3. Performance and economical parameters of weaned pigs, trial III

\begin{tabular}{|c|c|c|}
\hline Group & 1 & 2 \\
\hline Yeast, Crvenka & + & - \\
\hline Biokvas, Bankom & - & + \\
\hline \multicolumn{3}{|c|}{ Weaned pigs, $10-17 \mathrm{~kg}$} \\
\hline $\begin{array}{l}\text { Average live weight of piglets at the beginning of } \\
\text { experiment, } \mathrm{kg}\end{array}$ & 9.91 & 10.22 \\
\hline $\begin{array}{l}\text { Average live weight of piglets at the end of } 1^{\text {st }} \text { period of } \\
\text { experiment, } \mathrm{kg}\end{array}$ & 17.60 & 17.60 \\
\hline Average daily gain, $g$ & 275 & 264 \\
\hline In the comparison to $1^{\text {st }}$ group, $\%$ & - & -4.00 \\
\hline Average daily feed consumption, $\mathrm{kg}$ & 0.521 & 0.514 \\
\hline In the comparison to $1^{\text {st }}$ group, $\%$ & - & -1.34 \\
\hline Feed conversion ratio, kg & 1.90 & 1.95 \\
\hline In the comparison to $1^{\text {st }}$ group, $\%$ & - & -2.63 \\
\hline \multicolumn{3}{|c|}{ Weaned pigs, $17-24 \mathrm{~kg}$} \\
\hline $\begin{array}{l}\text { Average live weight of piglets at the beginning of the } \\
\text { experiment, } \mathrm{kg}\end{array}$ & 17.60 & 17.60 \\
\hline $\begin{array}{l}\text { Average live weight of piglets at the end of the } \\
\text { experiment, } \mathrm{kg}\end{array}$ & 23.00 & 23.80 \\
\hline Average daily gain, $g$ & 491 & 563 \\
\hline In the comparison to $1^{\text {st }}$ group, $\%$ & - & +14.66 \\
\hline Average daily feed consumption, $\mathrm{kg}$ & 0.971 & 1.081 \\
\hline In the comparison to $1^{\text {st }}$ group, $\%$ & - & +11.33 \\
\hline Feed conversion ratio, $\mathrm{kg}$ & 1.98 & 1.92 \\
\hline In the comparison to $1^{\text {st }}$ group, $\%$ & - & -3.03 \\
\hline \multicolumn{3}{|c|}{ Weaned pigs, $10-24 \mathrm{~kg}$} \\
\hline $\begin{array}{l}\text { Average live weight of piglets at the beginning of the } \\
\text { experiment, } \mathrm{kg}\end{array}$ & 9.91 & 10.22 \\
\hline $\begin{array}{l}\text { Average live weight of piglets at the end of the } \\
\text { experiment, } \mathrm{kg}\end{array}$ & 23.00 & 23.80 \\
\hline Average daily gain, $g$ & 335 & 348 \\
\hline In the comparison to $1^{\text {st }}$ group, $\%$ & - & +3.88 \\
\hline Average daily feed consumption, $\mathrm{kg}$ & 0.648 & 0.673 \\
\hline In the comparison to $1^{\text {st }}$ group, $\%$ & - & +3.86 \\
\hline Feed conversion ratio, $\mathrm{kg}$ & 1.93 & 1.93 \\
\hline In the comparison to $1^{\text {st }}$ group, $\%$ & - & 0 \\
\hline Age of weaned pigs at the end of exp., days & 75 & 75 \\
\hline \multicolumn{3}{|c|}{ Economic analysis of cost of gain } \\
\hline Cost of feed, $\%$ & 100.00 & 99.43 \\
\hline Feed conversion ratio, $\%$ & 100.00 & 100.00 \\
\hline Cost of gain of weaned pigs, $\%$ & 100.00 & 99.43 \\
\hline In the comparison to $1^{\text {st }}$ group, $\%$ & - & +0.57 \\
\hline
\end{tabular}


During entire rearing period, yeast in diet enabled realization of average daily gain of $335 \mathrm{~g}$, with consumption of food of $0,648 \mathrm{~kg} /$ animal/day and feed conversion of $1,93 \mathrm{~kg}$. Substitution of yeast with Biokvas lead to improvement of gain in average by $13 \mathrm{~g}$ or $3,88 \%$, increased consumption of food in average by $0,025 \mathrm{~kg}$ or $3,86 \%$, whereas feed conversion was at the level of animals fed diet with yeast.

Economical analysis of cost of mixture showed that based on consumed food, cost of diet containing Biokvas was somewhat lower, by $0,57 \%$ compared to diet with yeast.

Considering that the same feed conversion was realized $-1,93 \mathrm{~kg}$, cost of $\mathrm{kg}$ of gain of weaned piglets fed diet containing Biokvas was by $0,57 \%$ lower compared to group of piglets fed diet based on yeast.

Obtained results of the third trial showed that investigated protein feed Biokvas can substitute yeast which was determined as feed of high biological value (Damnjanović, 1991; Lucero et al., 2003), and it can be used up to $15 \%$ in mixtures for rearing piglets (Araujo et al., 2006), and due to better utilization of food improvement in gain is established of approx. 7\% (Lindemayer and Propstmeiere, 1995), partially because intestinal crypts and villus are more expressed in piglets (Peet-Schwering et al., 2007). Introduction of yeast in diets for pregnant sows and sows in lactation improves the gain in their piglets by approx. 6\% (Kim et al., 2008).

\section{Conclusion}

The effects of imported compared to domestic boars are investigated, two boar lines Tibor and Tempo were compared in regard to production performance of their offspring - piglets in rearing were investigated, and in the third trial the possibility for utilization of Biokvas as yeast substitute in nutrition of piglets in rearing was studied.

Obtained results showed that:

- considerably better production is realized with the improvement of gain by $17,8 \%$ and feed conversion by $12,2 \%$ as well as lower cost of gain by $12,16 \%$ in progeny of imported boars;

- no differences between weaned piglets offspring of two boar lines Tibor and Tempo were established;

- considering better gain in average by $3,88 \%$, and less expensive by $0,57 \%$, biokvas demonstrated that it can be succesfully used as protein feed instead of yeast in nutrition of piglets in rearing.

In general, justification for the use of imported boars and application of biokvas for the purpose of improvement of production of piglets in rearing was established. 


\section{Acknowledgment}

Research was financed by Ministry of Science and Technology Development, Republic of Serbia, project TR 20087.

We would like to thank the family Fencaroš from Platičevo for enabling us to carry out trials on their pig farm.

\section{Neki tehnološki aspekti poboljšanja kod prasadi u odgoju}

B. Živković, W. Migdal, Č. Radović

\section{Rezime}

U tri ogleda ispitivani su efekti korišćenja uvoznih u odnosu na domaće neraste, komparacija dvaju linija Tibora i Tempa, uvoznih nerastova na proizvodnju njihovih potomaka, prasadi u odgoju, a u poslednjem trećem ogledu mogućnosti korišćenja biokvasa kao zamene kvascu u ishrani prasadi u odgoju.

Ispitivanja, su izvedena na privatnoj farmi svinja Fencaroš u Platičevu Šabac. U eksperimente je uključeno ukupno 56 odbijene prasadi rase melezi Veliki Jorkšir x Švedski Landras. Ogledi su formirani neposredno pri zalučenju prasadi i trajali su 39 hranidbenih dana pri čemu su prasad bila iste starosti na zalučenju.

Dobijeni rezultati su pokazali da se:

- ostvaruje znatno bolja proizvodnja, poboljšanjem prirasta za $17,79 \%$ i konverzije hrane za $12,21 \%$ kao i jeftinijom cenom prirasta za $12,16 \%$ kod potomaka nerastova iz uvoza.

- nije bilo razlike kod odbijene prasadi korišćenjem dvaju linija nerasta iz uvoza Tibora ili Tempa.

- s obzirom na bolji, u proseku za $3,88 \%$, i za $0,57 \%$ jeftiniji prirast, biokvas se pokazao da kao proteinsko hranivo može vrlo uspešno zameniti kvasac $\mathrm{u}$ ishrani prasadi u odgoju.

U celini se pokazala opravdanost korišćenja nerastova iz uvoza kao i primena biokvasa u cilju unapređenja proizvodnje prasadi u odgoju.

\section{References}

ARAUJO L.F., JANQUEIRA O.M., LOPES E.L., ARAUJO DE C.S., ORTOLAN J.H., LAURENTIZ DE A. C. (2006): Dried yeast (Saccharomyces cerevisiae) utilization for piglets in the initial phase. Ciencia Rural, 36, 5, 1576-1581. 
BITTANTE G. (2003): Estimated breed additive effects and direct heterosis for growth and carcass traits of heavy pigs. Livestock Production Science, 34, 2, 101114.

BOTEMPO V., GIANCAMILLO DI A., SAVOINI G., DELL'ORTO V., DOMENGHINI C. (2006): Live yeast dietary supplementation acts upon intestinal morpho-functional aspects and growth in weanling piglets.

DAMNJANOVIĆ M. (1991): Uticaj stočnog kvasca dodatog hrani na proizvodne rezultate i zdravstveno stanje svinja u tovu. Doktorska disertacija, strana 116, Veterinarski fakultet, Beograd.

GAUGLER H.R., BUCHANAN D.S., HINTZ R.L., JOHNSON R.K. (1984): Sow reproductivity comparisons for four breeds of swine: purebred and crossbred litters. Journal of Animal Science, 59, 4, 941-947.

KLIMIENE A., KLIMAS R. (2008): Influence of Environmental Factors on Adaptation of Pigs. Proceedings $43^{\text {rd }}$ Croatian and $3^{\text {rd }}$ International Symposium on Agriculture, Opatija, Croatia, 819-822.

KOVČIN S. (1993): Ishrana svinja. Univerzitet u Novom Sadu, Poljoprivredni fakultet.

LINDEMAYER H., PROPSTMEIERE G. (1995): Live yeast cells for rearing piglets. Kraftfutter, 6, 274-277.

LUCERO M., LANZ G. E., MARTINEZ A. A., CUARON J.A., PAIEPREME A.C. ( 2003): Dosage and efficacy of a novel Sacccharomyces cerevisiae strain to enhance piglets productivity. Journal of Animal Science, 85, Suppl. 1.

MAGOWAN E., McCANN M. E.E., BEATTIE V.E., McCRACKEN K.J., HENRY W., SMYTH S., BRADFORD R., GORDON F.J., MAYNE C.S. (2007): Investigation of growth rate variation between commercial pig herds. Animal, 1, 8, 1219-1226.

McGLOGHLIN (2003): Growth and carcass quality of crossbred pigs sired by Duroc, Landrace and Large White boars. Livestock Production Science, 18, 4, 275288.

NCUBE M., DZAMA K., CHIMONYO K., KANENGONI A., HAMUDIKUWANDA H. (2003): Effect of boar genotype on reproductive performance of the local sows of Zimbabwe. Livestock research for Rural Development, 15, 2, 1-11.

OKE U.K., IBE S.N., OLOGBOSE F.I., AMAEFULA K.U. (2006): Effect of breed of sire on growth performance of exotic crossbred pigs in a humid tropical environment. Journal of Animal and Veterinary Advances, 5, 9, 744-748.

PEET-SCHWERING VAN DER C.M.C., JANSMAN A.J.M., SMIDT H., YOON I. (2007): Effect of yeast culture on performance, gut integrity, and blood cell composition of weanling pigs. Journal of Animal Science, 85, 3099-3109.

PETKOV P. (2007): Effect of introduction on mineral status in different pig breeds. Trakia Journal of Sciences, 3, 3-4, 24-29. 
SPARK M., PACHERTZ H., KAMPHUES J. (2005): Yeast (different sources and levels) as protein source in diets of reared piglets: effect on protein digestibility and N-metabolism. Journal of Animal Physiology and Animal Nutrition, 89, 3-6, 184188.

WIDOVSKI T.M., TORREY S., BENCH C.J., GONYOU H.W. (2008): Development of ingestive behavior and the realtionship to belly nosing in earlyweaned piglets. Applied Animal Behavior Science, 110, 1-2, 109-127.

ŽIVKOVIĆ B., MIGDAL W., KOVČIN S., RADOVIĆ Č., KOSOVAC O. (2007): Effect of using plant protein feed as a fish meal replacer in the nutrition of weaned piglets. Annals of Animal Science, Kraków, 7, 2, 273-278.

ŽIVKOVIĆ B., MIGDAL W., VESELINOVIĆ V., RADOVIĆ Č., FABJAN M., KOSOVAC O. (2008): Nutritive value of Ecofish meal in pig nutrition. Biotehnology in Animal Husbandry, 24, 5-6, 77-86.

ŽIVKOVIĆ B., VESELINOVIĆ V., MIGDAL W., CILEV G., KOSOVAC O., RADOVIĆ Č., MARINKOV G. (2007): Ekofish meal as fish meal substitute in nutrition of weaned piglets and fattening pigs. III Symposium of livestock production with international participation, Ohrid, 669-675.

ŽIVKOVIĆ S., KOVČIN S. (1986): Aktuelna dostignuća u odgoju i ishrani ranoodbijene prasadi. Pig production in mediterranean countries, Belgrade, April 21-24, 179-191. 